\section{OCCURRENCE OF ARGIOPE LOBATA (PALLAS, 1772) IN ROLLAPADU WILDLIFE SANCTUARY, ANDHRA PRADESH}

\section{Srinivasulu ${ }^{1}$, Bhargavi Srinivasulu', Manju Siliwal $^{2}$}

${ }^{1}$ Research Associate, Department of Zoology, Osmania University, Hyderabad,Andhra Pradesh 500 007, India

${ }^{2}$ Research Associate, Wildlife Information Liaison Development Society, 29/1, Bharathi Colony, Peelamedu, Coimbatore, Tamil Nadu 641004, India

Email: masawa@hd2. dot. net. in, manjusiliwal@rediffmail.com web supplement

Rollapadu Wildlife Sanctuary $\left(15^{0} 58^{\prime} \mathrm{N} \& 78^{0} 18^{\prime} \mathrm{E}\right)$, located in the Kurnool District of Andhra Pradesh is world renowned as home to two endangered species of birds, namely the Great Indian Bustard (Ardeotis nigriceps) and the Lesser Florican (Sypheotides indica). The first author has been monitoring and documenting the fauna of the Sanctuary since 1998. In December 2000, the first author sighted an unidentified Argiope sp. in the grasslands of Cherukucherla near the Rollapadu Wildlife Sanctuary. Later, the sighting frequency of this species increased and it was also noted within the Sanctuary. In the past three years quite a few individuals of this Argiope sp. were sighted. Careful observation of a live specimen encountered and the study of the photograph revealed that the species encountered by us was Argiope lobata (Pallas, 1772). A photo voucher of the same (NHM.OU/ARACH 2003 1P) has been deposited in the Natural History Museum of Department of Zoology, Osmania University, Hyderabad (see Image $1^{\mathrm{w}}$ ).

Argiope lobata (Pallas, 1772) is the only species of genus Argiope consisting of a caudal process, three large and two smaller tubercles on the abdomen. Carapace black with silky white pubescence. Dorsum of the abdomen is golden yellow to orange with transverse black patches between the tubercles and caudal process. Ventral side provided with U-shaped orange patch between epigynal region and spinnerets.

Argiope lobata (Pallas, 1772) is an uncommon species of the genus Argiope and generally found in grassland habitats. A total of seven individuals of this species (three individuals within the Sanctuary and four individuals outside the Sanctuary) were sighted between December 2000 and March 2003. Interestingly, all the specimens sighted were female specimens and search for the male specimens proved futile. The webs were about $0.6-1.2 \mathrm{~m}$ above ground and were more often on, but not restricted to, Agave sp. One web was observed stretched between Zizyphus mauritiana and Phoenix sylvestris. The web diameter ranged between $0.45-1.3 \mathrm{~m}$, with a ' $\mathrm{x}$ ' shaped stabilimentum across the centre or hub of the web.

This species is a 'wait and watch' type of predator that feeds on a variety of insects. It waits in the centre of the web for its prey to get entangled, then rushes to the spot, injects venom and starts wrapping the insect with silk (swathing bands) to make a cocoon-like structure. This mode of swathing the prey with silk ensures retention of moisture in the prey as the webs are constructed in places exposed to direct sunlight. When hungry, the spider moves the wrapped-up prey to the hub of the web to feed on. Exuvia of grasshoppers, crickets, beetles, moths, dragonflies were collected from the webs.

Recently, Argiope arcuata Simon,1884 was synonimised with Argiope lobata (Pallas, 1772) by Levi (1983). Pocock (1900) reported the occurrence of Argyope (=Argiope) arcuata Simon, 1884 in India from Poona (=Pune), East Khandesh (=Jalgaon Dist. in Maharashtra), Bangalore and in Burma (=Myanmar) from Minhla. Tikader $(1961,1963)$ also reported Argiope arcuata Simon, 1884 from Bikaner in Rajasthan and Ahmednagar in Maharashtra in India and indicated its occurrence in Arabia. The present day known distribution range of Argiope arcuata Simon, 1884 includes Tamil Nadu, Karnataka, Maharashtra, Bihar, Madhya Pradesh, Rajasthan and West Bengal (Tikader, 1982; Biswas \& Biswas, 1992). Our sighting of Argiope lobata (Pallas, 1772) from Rollapadu Wildlife Sanctuary and the surrounding grassland patches is the first report of its occurrence from Andhra Pradesh.

\section{ACKNOWLEDGEMENTS}

We thank the Chief Wildlife Warden, Andhra Pradesh Forest Department and other concerned officers for permission and encouragement. We also thank the Head, Department of Zoology, for providing us necessary facilities. The first two authors (CS \& BS) acknowledge individual research grants to them from CSIR, New Delhi.

\section{REFERENCES}

Biswas, B. and K. Biswas (1992). Araneae: Spiders. State Fauna Series 3: Fauna of West Bengal 3: 357-500.

Levi, H.W. (1983). The orb-weaver genera Argiope, Gea, and Neogea from the western Pacific region (Araneae: Araneidae, Argiopinae). Bulletin of the Museum of comparative Zoology Harvard 150: 247-338.

Pallas, P.S. (1772). Spicilegia zoologica. Tomus 1. Continens quadrupedium, avium, amphibiorum, piscium, insectorum, molluscorum aliorumque marinorum fasciculos decem. Berolini 1(9): 44-50.

Pocock, R.I. (1900). The fauna of British India, including Ceylon and Burma. Arachnida. London, pp.1-279.

Simon, E. (1884). Arachnides recueillis en Birmanie par M. le chevalier J.B. Comotto et appartenant au Musée civique d'histoire naturelle de Gènes. Annali del Museo civico di storia naturale di Genova 20: 325372 .

Tikader, B.K. (1961). On a collection of spiders (Araneae) from the Desert areas of Rajasthan (India). Records of the Indian Museum 59: 435-443.

Tikader, B.K. (1963). Studies on some spider fauna of Maharashtra and Mysore States. Journal of University Science and Technology 24: 29-54. Tikader, B.K. (1982). Family Araneidae (= Argiopidae), typical orbweavers. Fauna of India (Araneae) 2: 1-293.

${ }^{w}$ See Image 1 of the spider on the web at www.zoosprint.org 